\title{
The Effect of Supplementation of Avocado Seed Flour (Persea americana Mill.) in Feed on Blood Lipids Profile and Egg Yolk Cholesterol of Japanese Quail (Corturnix-corturnix japonica)
}

\author{
Yosua Sujud Apriyanto ${ }^{1 *}$, Ning Iriyanti ${ }^{2}$ and Elly Tugiyanti ${ }^{2}$ \\ ${ }^{1}$ Graduate Program, Faculty of Animal Science, Jenderal Soedirman University, Purwokerto, Central Java, Indonesia \\ ${ }^{2}$ Faculty of Animal Science, University of Jenderal Soedirman, Purwokerto, Central Java, Indonesia \\ *Corresponding author email: sujudyosua@yahoo.co.id
}

\begin{abstract}
The purpose of this research is to determine the effect of avocado seed flour (ASF) supplementation in feed on blood lipids and quail egg yolk cholesterol. The materials were 100 female quails aged 4 weeks old with ration ingredients consist of corn, bran, paddy, soybean meal, fish flour, avocado seed flour, palm oil, $\mathrm{CaCO}_{3}$, premix, lysine, and methionine. The research conducted an experiment with 4 treatments of ASF supplementation levels incorporated into basal feed, namely 0\% ASF (Ro), 3\% ASF ( $\left.R_{1}\right), 6 \%$ ASF $\left(R_{2}\right)$, and 9\% ASF $\left(R_{3}\right)$. The observed variables included blood cholesterol, High Density Lipoprotein (HDL), Low Density Lipoprotein (LDL), triglyceride, and egg yolk cholesterol. The data were subjected to the one-way Analysis of variance (ANOVA) in a completely randomized design, followed by HSD test when differences between treatments were observed. The result showed that ASF supplementation significantly reduced blood cholesterol levels and the egg yolk cholesterol, did not significantly affect LDL and triglyceride levels. The HDL levels and egg yolk cholesterol tend to decrease as the level of ASF increased. It is concluded that avocado seed flour (ASF) supplementation up to $9 \%$ is safe for quail feed supplementation.
\end{abstract}

Keywords: female quail, ration ingredients, blood lipids, avocado seed flour [ASF]

Abstrak. Tujuan penelitian ini adalah mengetahui pengaruh suplementasi tepung biji alpukat dalam pakan terhadap profil lemak darah dan kolesterol kuning telur puyuh. Materi yang digunakan adalah puyuh betina umur 4 minggu sebanyak 100 ekor. Bahan ransum terdiri dari: Jagung, dedak padi, bungkil kedelai, tepung ikan, tepung biji alpukat, minyak sawit, $\mathrm{CaCO}$, premix, lisin dan metionin. Rancangan yang digunakan adalah eksperimen, terdiri dari 4 perlakuan yaitu: pakan basal dengan suplementasi TBA 0\% (Ro), pakan basal dengan suplementasi TBA 3\% $\left(R_{1}\right)$, pakan basal dengan suplementasi TBA $6 \%\left(R_{2}\right)$, dan pakan basal dengan suplementasi TBA $9 \%\left(R_{3}\right)$. Variabel yang diamati meliputi: kolesterol darah, HDL (High density lipoprotein), LDL (Low density lipoprotein), trigliserida dan kolesterol kuning telur. Analisis yang digunakan ANOVA (Analysis of Varians) dengan Rancangan Acak Lengkap pola searah. Apabila ada perbedaan antar perlakuan dilakukan uji BNJ. Hasil penelitian menunjukkan bahwa suplementasi TBA dapat menurunkan kadar kolesterol darah secara signifikan, dan kolesterol kuning telur, tetapi tidak berpengaruh nyata pada kadar LDL dan trigliserida. Kadar HDL dan kolesterol kuning telur cenderung berkurang seiring meningkatnya taraf TBA. Suplementasi tepung biji alpukat sampai $9 \%$ dapat digunakan sebagai suplementasi pakan puyuh.

Kata kunci: puyuh betina, ransum pakan, lemak darah, tepung biji alpukat (TBA)

\section{Introduction}

Quail is one of the various livestock in Indonesia with excellent economic and nutritional value. Quail meat and eggs are relatively affordable for consumers but have a high fat content that potentially increases the cholesterol level of the consumers. Quail eggs have approximately $13.1 \%$ protein and $11.1 \%$ fat content (Ujilestari et al., 2015), $869.57 \mathrm{mg} / 100 \mathrm{~g}$ cholesterol levels, and $5297.0 \mathrm{mg} / 100 \mathrm{~g}$ nonessential fatty acids (Aviati et al., 2014;
Tunsaringkarn et al., 2013). Furthermore, Tsalissavrina et al. (2013) reported that consuming saturated fats and high cholesterol in foods would increase the amount of cholesterol and the LDL blood. Efforts can be made to reduce cholesterol, LDL, and blood triglyceride levels by supplementing avocado seed flour.

Avocado seeds are considered avocado waste that is not popular for poultry feed ingredients. The benefits of avocado seeds include starch content up to $74.47 \%$ and antioxidant minerals 
like $\mathrm{Fe}, \mathrm{Mg}, \mathrm{Zn}$, Vitamin $\mathrm{C}$, Vitamin $\mathrm{E}$, and fatty acid (Orhevba et al., 2011; Vinha et al., 2013; Aliakbarzadeh et al., 2016). Compounds like phenolic, tannin, saponin, flavonoid, Vitamin C, and Vitamin $E$ in avocado seeds can reduce triacylglycerol, total cholesterol, and LDL-C (Low Density Lipoprotein-Cholesterol) levels because they protect the mucous membranes from lipid peroxide and prevents free radicals (Henry et al., 2015; Shehata and Soltan, 2013; Vinha et al., 2013). Lipase enzymes in avocado seeds are perceived to play a role in triglycerides degradation in the bloodstream, thereby reducing triglyceride levels. It confirms Sya'bani et al. (2017) that avocado seeds have lipase enzyme activity.

Flavonoids, tannins, and saponins in avocado seeds can inhibit the production of cholesterol in the liver synthesized by the ACAT (acylCoAcholesterol acyltransferase) enzyme (Henry et al., 2015; Shehata and Soltan, 2013). Cholesterol in the liver will then be sent via VLDL lipoprotein to the body tissues, including the formation of egg follicles; therefore, the decreased blood cholesterol is followed by decreased LDL and triglycerides and increased HDL of quail blood. The present study on the supplementation of avocado seed flour (ASF) aims to determine to what extent it affects the reduction of cholesterol levels, LDL, triglycerides, egg yolk cholesterol and the increase of blood HDL levels.

\section{Materials and Methods}

The study used 100 four-week-old-Japanesefemale-quails (corturnix corturnix japonica). The prepared feed ingredients consisted of corn, rice bran, soybean meal, fish flour, avocado seed flour (ASF), palm oil, $\mathrm{CaCO}_{3}$, premix, lysine and methionine.

Table 2. Composition and feed ingredients nutrition of quail

\begin{tabular}{|c|c|c|c|c|}
\hline Feed ingredientc & $\mathrm{R}_{0}$ & $\mathrm{R}_{1}$ & $\mathrm{R}_{2}$ & $\mathrm{R}_{3}$ \\
\hline 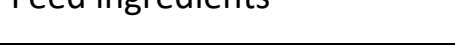 & & & & \\
\hline Corn & 40 & 40 & 40 & 40 \\
\hline Rice bran & 29 & 29 & 29 & 29 \\
\hline Soybean meal & 20 & 20 & 20 & 20 \\
\hline Fish meal & 8 & 8 & 8 & 8 \\
\hline Avocado seed flour & 0 & 3 & 6 & 9 \\
\hline Palm oil & 2.0 & 2 & 2 & 2 \\
\hline Calcium carbonate ( $\mathrm{CaCO} 3$ ) & 0.4 & 0.4 & 0.4 & 0.4 \\
\hline Premix & 0.2 & 0.2 & 0.2 & 0.2 \\
\hline Lysine & 0.2 & 0.2 & 0.2 & 0.2 \\
\hline Methionine & 0.2 & 0.2 & 0.2 & 0.2 \\
\hline Total & 100 & 103 & 106 & 109 \\
\hline \multicolumn{5}{|l|}{ Nutrition Composition } \\
\hline Crude Protein $(\%)^{1)}$ & 20.34 & 20.51 & 20.69 & 20.86 \\
\hline $\mathrm{ME}(\mathrm{kkal} / \mathrm{kg})^{2)}$ & 2928.3 & 3044.8 & 3161.2 & 3277.6 \\
\hline Extract ether $(\%)^{1)}$ & 5.86 & 6.08 & 6.30 & 6.52 \\
\hline Crude Fiber $(\%)^{1)}$ & 4.72 & 4.81 & 4.91 & 5.00 \\
\hline $\mathrm{Ca}(\%)^{2)}$ & 0.88 & 0.88 & 0.88 & 0.88 \\
\hline$P(\%)^{2)}$ & 1.22 & 1.23 & 1.23 & 1.24 \\
\hline Lysine $(\%)^{2)}$ & 1.24 & 1.24 & 1.24 & 1.24 \\
\hline Methionine $(\%)^{2)}$ & 0.56 & 0.56 & 0.56 & 0.56 \\
\hline
\end{tabular}


The avocado seed flour was made by soaking and boiling the avocado seeds for \pm 10 minutes, removing the husk from the seeds, cutting to $\pm 2 \mathrm{~mm}$, and sun-drying for $\pm 3-5$ days. The present study conducted an experiment in a completely randomized design (CRD) with 4 treatments and 5 replicates ( 5 quails each). The treatments were the level of ASF supplementation incorporated into basal feed, namely $R_{0}(0 \% A S F), R_{1}$ (3\% ASF), $R_{2}(6 \% A S F)$, and $R_{3}$ ( $9 \%$ ASF). The preliminary study was conducted for one week.

Quail blood sampling was taken at the end of the research. Exactly $\pm 2 \mathrm{ml}$ of blood was drawn from the brachial vein at the bottom of the wing using a 3-ml syringe, then contained in EDTA (Ethylene Diamine Tetra Acetic) (anticoagulant) tube.

The analysis of cholesterol, HDL, LDL, and triglyceride levels was performed using the Cholesterol Hydrolyze-Oxidase (CHOD-PAP) method, while blood triglyceride level was measured using the Calorimetric Enzymatic testGlycerol 3 Phosphate-oxidase (GPO-PAP) method (Citrawidi et al., 2012; Arrosichin et al., 2016). The analysis of egg yolk cholesterol was measured using the CHOD-PAP method (Suciningtyas, 2016). The variables observed in this research were the blood lipids profiles including cholesterol, HDL (High-Density Lipoprotein), LDL (Low-Density Lipoprotein) and triglycerides. The data obtained were tabulated and subjected to analysis of variance (ANOVA), followed by HSD test (Honestly Significant Difference).

\section{Results and Discussion}

\section{Blood lipids profiles}

The results of blood lipids profiles (cholesterol, HDL, LDL and triglycerides) after with supplemented with avocado seed flour are presented in Table 1.

\section{Blood cholesterol}

The average blood cholesterol level after supplementation of avocado seed flour (ASF) was $199.3 \pm 26.0 \mathrm{mg} / \mathrm{dL}$ while in the control feed $\left(R_{0}\right)$ was $237.8 \pm 49.4 \mathrm{mg} / \mathrm{dL}$. This result is generally lower than $230.64 \mathrm{mg} / \mathrm{dL}$ in a study by Dogan et al. (2016) using 10-week-old-quails. The result of analysis of variance showed that the supplementation of ASF significantly affected $(P<0.05)$ blood cholesterol levels because the bioactive compounds in ASF were perceived to inhibit cholesterol synthesis in the liver through ACAT (acyl-CoA cholesterol acyl transferase) enzyme activity. Further HSD test showed that quails fed with $9 \%$ ASF had a considerably lower cholesterol level (Table 1). It is evident that the higher the level of avocado seeds, the lower the blood cholesterol. Similarly, Uchenna et al. (2017) reported that avocado seeds flour up to $4 \%$ can reduce the blood cholesterol in rats.

Table 1. Blood lipids profile of 13-weeks-old-quail offered with avocado seed flour supplementation

\begin{tabular}{|c|c|c|c|c|}
\hline \multirow{2}{*}{ Treatment } & Cholesterol* & $\mathrm{HDL}^{\mathrm{ns}}$ & $\mathrm{LDL}^{\mathrm{ns}}$ & Triglycerides $^{\text {ns }}$ \\
\hline & \multicolumn{4}{|c|}{ (1) } \\
\hline $0 \%$ & $237.8 \pm 49.4^{b}$ & $34.2 \pm 7.1$ & $203.6 \pm 54.3$ & $357.1 \pm 159.1$ \\
\hline $3 \%$ & $222.2 \pm 28.3^{b}$ & $31.9 \pm 8.4$ & $190.3 \pm 34.7$ & $277.1 \pm 123.1$ \\
\hline $6 \%$ & $204.4 \pm 28.9^{\mathrm{ab}}$ & $28.4 \pm 10.1$ & $176.0 \pm 36.8$ & $277.1 \pm 86.7$ \\
\hline $9 \%$ & $171.1 \pm 26.8^{\mathrm{a}}$ & $22.2 \pm 6.5$ & $148.9 \pm 30.3$ & $231.4 \pm 49.9$ \\
\hline Average $R_{1}, R_{2}, R_{3}$ & $199.3 \pm 26.0$ & $27.5 \pm 5.0$ & $171.7 \pm 21.0$ & $261.9 \pm 26.4$ \\
\hline
\end{tabular}

Note: ${ }^{a, b}$ different superscripts at the same column indicate significant differences $(P<0.05) ;{ }^{*}$ significant different $(P<0.05) ;^{\text {ns }}$ non significant $(P>0.05)$. 


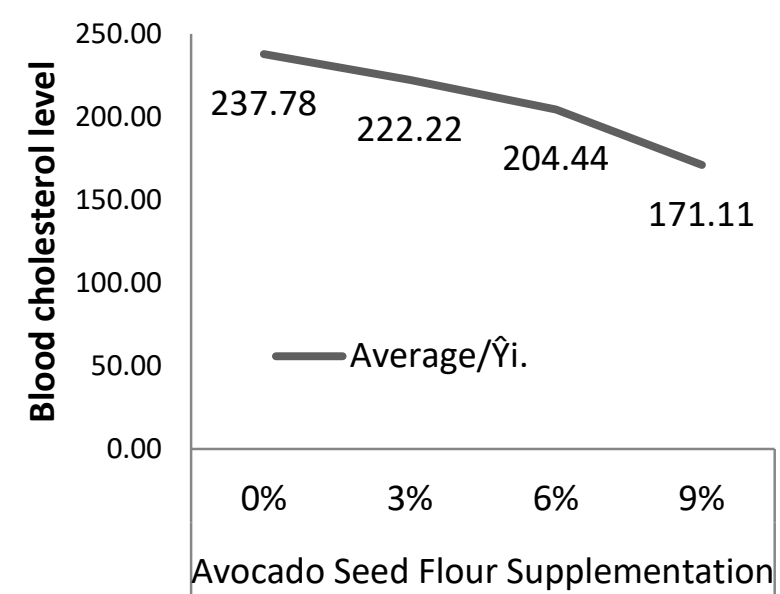

Chart 1. The blood cholesterol level of 13-weeks-oldquail

According to Henry et al. (2015) and Shehata and Soltan (2013), flavonoids in avocado seeds can lower triacylgliserol, total cholesterol, and LDL-C (Low Density Lipoprotein-Cholesterol) by protecting against lipid peroxide and preventing free radicals. This research found that avocado seed flour contained $5.41 \%$ flavonoids, which is perceived to affect the decreased quail blood cholesterol levels in quails.

The flavonoid component in avocado seeds is assumed to play a role in inhibiting cholesterol synthesis in the liver through the enzyme acylCoA cholesterol acyltransferase (ACAT) so that the cholesterol produced is small. It is in line with Shehata and Soltan (2013) that avocado seeds contain a component of flavonoids, i.e., rosmarinic with the amount of $114.19 \mu \mathrm{g} / 100 \mathrm{~g}$. According to Fadel et al. (2011), it is evident that rosmarinic compounds in the flavonoid group can prevent lipid peroxides by permeating the membrane close to lipid groups that can be accessed by polar molecules, such as watersoluble radicals.

\section{High-Density lipoprotein (HDL)}

The average of HDL blood level after the supplementation of avocado seed flour (ASF) is $27.5 \pm 5.0 \mathrm{mg} / \mathrm{dL}$ while in control treatment $\left(R_{0}\right)$ is $34.2 \pm 7.1 \mathrm{mg} / \mathrm{dL}$ (Table 1 ). This result is generally higher than $8.25 \mathrm{mg} / \mathrm{dL}$ to $18.75 \mathrm{mg} / \mathrm{dL}$ in a study by Shenatmoko et al. (2013) using 14 week-old quails. The results of the analysis of variance shows that ASF supplementation had no significant effect $(P>0.05)$ on HDL levels of quail blood. It is suspected that the saturated fatty acids in avocado seeds contain some components that inhibit LCAT enzymes and Bcomplex as the protein maker of HDL-forming material, APO 1. According to Arrosichin et al. (2016) niacin is a vital part of B-Complex in oxidation and reduction because it serves as coenzyme NAD (Nicotin Amide-adenine Dinucleotide) and NADP (Nicotin Amide-adenine Dinucleotide Phosphate) that increase the apolipoprotein A-1 and stimulate HDL synthesis.

The fatty acid in avocados plays a role in inhibiting blood HDL production (Aliakbarzadeh et al. 2016). According to Aliakbarzadeh et al. (2016) Avocado seeds contain saturated fatty acids, such as lauric $(<17,94 \mathrm{mg} / \mathrm{kg})$, myristic $(11,92 \mathrm{mg} / \mathrm{kg})$ and palmitic $(474,32 \mathrm{mg} / \mathrm{kg})$. Heryani (2016) explains that the low HDL is due to polyunsaturated fatty acids which decreases the apoprotein A-1 as the precursor for the formation of HDL. Furthermore, Kochikuzhyil et al. (2010) stated that HDL decreased when palmitic acid was metabolized into palmitoleic acid. Saturated fats and unsaturated fats could minimize the reduction of HDL and cholesterol levels, while palmitic acid to palmitoleic acid ration is negatively correlated to HDL levels. (Siri et al., 2010; Morse, 2015).

Fatty acids, especially saturated fatty acids, are atherogenic which triggers the narrowing and thickening of blood vessel walls, as well as eliminates the enzyme activity in fat metabolism, such as elongase fatty acid desaturase and LCAT (Lecithin Cholesterol Acyltransferase) (Meisyahputri and Ardiaria, 2017). LCAT (Lecithin Cholesterol Acyltransferase) plays a vital role in the formation and maturation of HDL with the increased expenditure of Apolipoprotein A-1 (Apo-1) as an HDL-forming protein. Supplementing avocado seed flour may reduce HDL levels, but the quails might not show negative health status during the research. It is 
due to a balance between flavonoids and saturated fatty acids in avocado seeds which can maintain the stability of HDL in the bloodstream.

\section{Low-Density lipoprotein (LDL)}

The average of LDL blood level after the supplementation of avocado seed flour is $171.7 \pm 21.0 \mathrm{mg} / \mathrm{dL}$, the control treatment $\left(R_{0}\right)$ is $203.6 \pm 24.3 \mathrm{mg} / \mathrm{dL}$ (Table 1). This number tends to be greater when compared to the results of Shenatmoko et al. (2013) and Arrosichin et al. (2016) with quail, aged 11 and 14 weeks old, for $115.37 \mathrm{mg} / \mathrm{dL}$ and $168.38 \mathrm{mg} / \mathrm{dL}$ respectively. The amount of LDL can be influenced by the formation of cholesterol in the liver, the less cholesterol is formed, then the amount of LDL produced will also decrease.

The results of variance analysis shows that supplementation of avocado seed flour had no significant effect $(P>0.05)$ on the LDL level of quail blood, this is thought to have saturated fatty acid content that can increase LDL. This shows that the content of tannins, flavonoids and saponins that play a role in inhibiting LDL production is not optimal. According to SiriTarino et al. (2010), the components of saturated fatty acids can affect LDL, such as lauric acid, myristic and palmitate are known to increase the amount of serum LDL, this ability can occur when followed by high feed cholesterol intake. It is known that there is a balance between the amount of saturated fatty acids and flavonoids in avocado seeds that play a role in balancing the amount of LDL in the bloodstream, so it does not cause cholesterol deposition in blood vessel endothelial tissue which results in decreased quail body weight.

\section{Triglycerides}

The average of triglyceride blood level after the supplementation of avocado seed flour is $261.9 \pm 26.4 \mathrm{mg} / \mathrm{dL}$ and the control treatment $\left(R_{0}\right)$ is $357.1 \pm 159.1 \mathrm{mg} / \mathrm{dL}$ (Table 1 ). This number tends to be smaller when compared to Dogan et al. (2016) triglyceride levels at 10 weeks old quail of $516.6 \mathrm{mg} / \mathrm{dL}$. The results of the variance analysis shows that avocado seed flour supplementation had no significant effect ( $P>0.05)$ on quail triglyceride blood levels. It is suspected that the alkaloid contained in avocado seeds can inhibit the activity of the lipoprotein lipase enzyme as an ingredient to break down blood triglycerides, but numerically as the avocado seed flour increases, the amount of quail triglycerides blood decreases.

The mechanism of triglyceride reduction starts from HMG-CoA reductase inhibitor compounds which can inhibit cholesterol synthesis in the liver, so the formation of VLDL (Very Low Density Lipoprotein) in the liver will also be inhibited, so triglyceride levels increase (Orbayinah and Permana, 2016). According to Budiarto and Yuniwarti (2016), alkaloids can inhibit the performance of the lipase enzyme in the digestive tract so that it absorbs reduced body fat. Reinforced by the opinion of Tsalissavrina et al. (2013) which causes a decrease in lipase enzyme caused by insulin resistance, it will increase triglyceride blood levels. Giving avocado seed flour containing lipase and alkaloid enzymes can stabilize triglyceride blood levels, so there is no increase in triglyceride blood levels.

\section{Egg yolk cholesterol}

The results of cholesterol of quail egg yolk after the supplementation of avocado seed flour are presented in Chart 2.

The average cholesterol level of egg yolk with avocado seed flour supplementation is $382.8 \pm 14.9 \mathrm{mg} / 100 \mathrm{~g}$, with $\mathrm{R}_{0}$ treatment is $445.40 \pm 26.46 \mathrm{mg} / 100 \mathrm{~g}$ (Graph 2). This result is different compared to the research of Aviati et al. (2014) amounting to $869.57 \mathrm{mg} / 100 \mathrm{~g}$, and Djaelani (2018) of $632.46 \mathrm{mg} / 100 \mathrm{~g}$. The results of the analysis of variance shows that the supplementation of avocado seed flour had a 


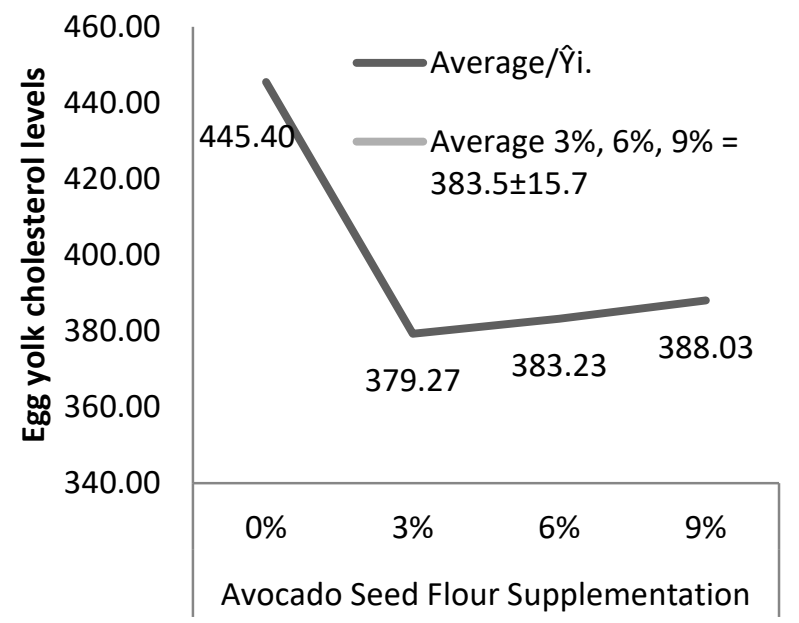

Chart 2. 13-weeks-old quail egg yolk cholesterol levels

very significant effect $(P<0.01)$ on the cholesterol levels of quail egg yolks. It is suspected that the avocado polyphenols and saponins can inhibit the formation of steroid hormones.

Further test is done with HSD (Honestly Significant Difference) test (Table 2), shows that quail which fed with avocado seed flour supplementation at the level of $3 \%$, resulting egg yolk cholesterol levels quite low compared to other treatments. The amount of cholesterol in egg yolk correlates with blood cholesterol. It is appropriate that there is a tendency to reduce cholesterol in yolk followed by the amount of blood cholesterol.
Avocado seeds that contain saponins can inhibit the absorption of cholesterol in the body (Shehata and Soltan, 2013; Vinha et al., 2013). According to Afrose et al. (2010), saponin is a steroid glycoside or triterpene with potential to reduce cholesterol, and they prove that saponins can lower the cholesterol concentration of egg yolk.

Siregar (2015) explained that saponins will reduce cholesterol by binding to bile acids to form micelles so that they cannot be absorbed by the intestine. Thus saponins will bind cholesterol as an ingredient in the formation of steroid hormones in the liver and inhibit vitellogenin synthesis as a pathway for egg follicle formation.

Polyphenol compounds could be able to inhibit the amount of cholesterol in the endoplasmic reticulum. In accordance with the opinion of Aviati et al. (2014), that in the endoplasmic reticulum, fatty acids and cholesterol are taken from the liver to the entire body in the form of endogenous or lipoprotein, then fatty acids will be synthesized into triglycerides and join cholesterol, phospholipids, and proteins to VLDL (Very Low-Density Lipoprotein) to carry throughout the body's tissues including ovarian follicles so that cholesterol levels in eggs can be affected by the presence of an endogenous cholesterol count.

Table 2. Further Cholesterol Test Results for Quail Egg Yolk

\begin{tabular}{|c|c|c|c|}
\hline \multirow{2}{*}{ Avocado Seed Flour Supplementation } & \multirow{2}{*}{$\mathrm{N}$} & \multicolumn{2}{|c|}{ Subset for alpha $=0.01$} \\
\hline & & 1 & 2 \\
\hline $3 \%$ & 5 & $379.27^{\mathrm{a}}$ & \\
\hline $6 \%$ & 5 & $383.23^{\mathrm{a}}$ & \\
\hline $9 \%$ & 5 & $388.03^{\mathrm{a}}$ & \\
\hline $0 \%$ & 5 & & $445.40^{b}$ \\
\hline Sig. & & 0.888 & 1.000 \\
\hline
\end{tabular}

Note: ${ }^{a, b}$ different superscripts at the same column indicate significant differences $(P<0.01)$

\section{Conclusions and Recommendations} Conclusions

Avocado seed flour (ASF) can significantly reduce blood cholesterol by $171.11 \mathrm{mg} / \mathrm{dL}$ and egg yolk cholesterol by $379.27 \mathrm{mg} / 100 \mathrm{~g}$, but not LDL and triglyceride levels. HDL blood levels tend to decrease as the levels of avocado seed flour increase. Overall, avocado seed flour 
supplementation in quail feed did not have negative impacts on quail health status and final body weight. Supplementation of avocado seed flour up to $9 \%$ is viable for ration to quails in layer phase.

\section{Recommendations}

The process of boiling avocado seeds should be under $80^{\circ} \mathrm{C}$. This is necessary to ensure as few nutrients escape during the boiling, and the avocado seeds should be sun-dried between $8: 00$ and 17:00. Additionally, it is vital to avoid white spots or fungi during the drying process in the next day.

\section{References}

Afrose, S, MS Hossain, and H Tsujii. 2010. Effect of dietary karaya saponin on serum and egg yolk cholesterol in laying hens. Br. Poult. Sci. 51(6):797-804.

Aliakbarzadeh, G, H Sereshti, and H Parastar. 2016. Fatty acids profiling of avocado seed and pulp using gas chromatography-mass spectrometry combined with multivariate chemometric techniques. J. Iranian Chem. Soc. 13(10):19051913.

Arrosichin, K, VD Yunianto, and F Wahyono. 2016. Kandungan kolesterol, high density lipoprotein (hdl) dan low density lipopro-tein (Idl) darah burung puyuh dengan pemberian aditif cair buah naga merah. JIP. 26(1):16-22.

Aviati, V, SM Mardiati, and TR Saraswati. 2014. Kadar kolesterol telur puyuh setelah pemberian tepung kunyit dalam pakan. Buletin Anatomi Fisiologi dan Sellula. 22(1): 58-64.

Budiarto, MA, and EYW Yuniwarti. 2016. Pengaruh pemberian tepung daun jati Belanda (Guazuma ulmifolia L.) dalam pakan terhadap kadar trigliserida darah dan lemak abdominal ayam broiler. Buletin Anatomi Fis. 1(1) : 43-47.

Citrawidi, TA, W Murningsih, and VDYB Ismadi. 2012. Pengaruh pemeraman ransum dengan sari daun pepaya terhadap kolesterol darah dan lemak total ayam broiler. Anim. Agric. J. 1(1):529-540.

Djaelani, MA. 2018. Suplementasi tepung kulit kayu manis dan daun pegagan dalam pakan terhadap kandungan kolesterol dan antioksidan telur puyuh. Bioma: J. Ilmiah Biologi. 7(1):65-81.

Dogan, SC, M Baylan, Z Erdogan, GC Akpinar, A Kucukgul, and V Duzguner. 2016. Performance, egg quality and serum parameters of japanese quails fed diet supplemented with Spirulina platensis. Fres. Env. Bull. 25(25):5857-5862.
Fadel, O, K. El Kirat, and S Morandat. 2011. The natural antioxidant rosmarinic acid spontaneously penetrates membranes to inhibit lipid peroxidation in situ. BBABiomembranes. 1808(12):2973-2980.

Henry, LN, UY Mtaita, and CC Kimaro. 2015. Nutritional efficacy of avocado seeds. Glob. J. Food Sci. Tech. 3(5):192-196.

Heryani, R. 2016. Pengaruh ekstrak buah naga merah terhadap profil lipid darah tikus putih hiperlipidemia. JIT. 10(1):9-17.

Kochikuzhyil, BM, K Devi, and SR Fattepur. 2010. Effect of saturated fatty acid-rich dietary vegetable oils on lipid profile, antioxidant enzymes and glucose tolerance in diabetic rats. Indian J. Pharmacol. 42(3):142-145.

Meisyahputri, B, and M Ardiaria. 2017. Pengaruh pemberian kombinasi minyak rami dengan minyak wijen terhadap kadar kolesterol high density lipoprotein (HPL) tikus Sprague Dawley dislipidemia. Doctoral Dissertation, Diponegoro University, Semarang.

Morse, N. 2015. Lipid-lowering and anti-inflammatory effects of palmitoleic acid: evidence from preclinical and epidemiological studies. Lipid Tech. 27(5):107-111.

Orbayinah, S, and KE Permana. 2016. Pengaruh ekstrak buah anggur merah (Vitis vinifera L) terhadap kadar trigliserida darah tikus putih (Rattus novergicuss). Mutiara Medika: JKK. 11(3):175-180.

Orhevba, BA, and AO Jinadu. 2011. Determination of physico-chemical properties and nutritional contents of avocado pear (Persea americana M.). ARI. 1(3):372-380.

Shehata, MMSM, and SS Soltan. 2013. Effects of bioactive component of kiwi fruit and avocado (fruit and seed) on hypercholesterolemic rats. World J. of Dairy and Food Sci. 8(1):82-93.

Shenatmoko, AD, A Kurniawan, GC Gumilar, A Ratriyanto, R Indreswari, and R Dewanti. 2013. Pengaruh suplementasi betain terhadap beberapa parameter lipida dan protein darah pada puyuh. Sains Peternakan. 11(1):14-18.

Siregar, RNI. 2015. The effect of Eugenia polyantha extract on LDL cholesterol. J. Majority. 4(5):85-92.

Siri-Tarino, PW, Q Sun, FB Hu, and RM Krauss. 2010. Saturated fatty acids and risk of coronary heart disease: modulation by replacement nutrients. CAR. 12(6):384-390.

Suciningtyas, CP. 2016. Pengaruh ransum yang mengandung tepung buah mengkudu (Morinda citrifolia L.) terhadap kandungan kolesterol dan warna yolk telur puyuh (Cortunix cortunix japonica). Students e-journal, 5(2):1-10. 
Sya'bani, N, W Astuti, and DR Pratiwi. 2017. Isolasi dan karakterisasi lipase dari kecambah biji alpukat (Persea americana Mill). J. Atomik. 2(2):209-212.

Tsalissavrina I, D Wahono and D Handayani. 2013. Pengaruh pemberian diet tinggi karbohidrat dibandingkan diet tinggi lemak terhadap kadar trigliserida dan HDL darah pada Rattus novergicus galur wistar. J. Kedokteran Brawijaya. 22(2):80-89.

Tunsaringkarn T, W Tungjaroenchai and W Siriwong. 2013. Nutrient benefits of quail (Coturnix coturnix japonica) Eggs. IJSRP. 3(5):1-8.

Uchenna UE, AB Shori and AS Baba. 2017. Inclusion of avocado (Persea americana) seeds in the diet to improve carbohydrate and lipid metabolism in rats. RAEM. 54(3):140-148.

Ujilestari T, S Kismiati and E Suprijatna. 2015. Pengaruh penggunaan tepung limbah rumput laut (Gracilaria verrucosa) terfermentasi dalam ransum terhadap kualitas kimiawi telur puyuh (Coturnix coturnix japonica). Anim. Agric. J. 4(1):115-20.

Vinha AF, J Moreira and SV Barreira. 2013. Physicochemical parameters, phytochemical composition and antioxidant activity of the Algarvian avocado (Persea americana Mill.). J. of Agric. Sci. 5(12):100-109. 